\title{
An Unusual Presentation of Large B-cell Lymphoma
}

\author{
Joel Robinette ${ }^{1}$, Chris White ${ }^{2}$ \\ 1. Otolaryngology / Surgery, West Virginia School of Osteopathic Medicine, Lewisburg, USA 2. Otolaryngology, \\ Greenbrier Valley Medical Center, Fairlea, USA
}

Corresponding author: Joel Robinette, robinette0304@gmail.com

\begin{abstract}
Primary Non-Hodgkin's lymphoma of the lacrimal sac is extremely rare. Symptoms are usually atypical and nonspecific, which often leads to the original misdiagnosis of dacryocystitis. The most common presenting features are epiphora, swelling, and acute dacryocystitis. We present a case of a 67-year-old female with primary diffuse large B-cell lymphoma (DLBCL) of the lacrimal sac, which was originally diagnosed as dacryocystitis. This case report adds to the urgency that prompt and precise diagnosis and treatment is key.
\end{abstract}

Categories: Ophthalmology, Otolaryngology

Keywords: dacryocystitis, lymphoma, lacrimal sac tumors, diffuse large b-cell lymphoma

\section{Introduction}

Malignancy of the lacrimal sac is rare; $6 \%$ of which are lymphomas [1]. In the immunocompetent, primary lymphoma occurs at a rate of $0.3 \%$ per 100,000 persons [2]. Of all primary lacrimal sac tumors, primary diffuse large B cell lymphoma (DLBCL) occurs at 43\%, MALToma at 24\%, unclassified B-cell lymphoma at $21 \%$, lymphoid hyperplasia at $5 \%$, and each small lymphocytic lymphoma and natural killer (NK)/T-cell lymphoma at 3\% [3]. One of the most common presenting features of DLBCL is dacryocystitis, which is a blockage of the nasolacrimal duct leading to an infection of the lacrimal sac [3]. The symptoms of DLBCL are usually atypical and nonspecific, which often leads to the original diagnosis with dacryocystitis [4-5]. The most presenting features are epiphora (96\%), swelling in the lacrimal sac region (75\%), and acute dacryocystitis (31\%) [3]. Patients with primary lacrimal sac tumors are often older and female [6].

We present a case of a 67-year-old woman with DLBCL of the lacrimal sac who was originally diagnosed with dacryocystitis. She presented with an overflow of tears onto the face (epiphora), swelling, and intermittent pressure on the left eye. Herein, we highlight the importance of early diagnosis and treatment for atypical presentations of lymphoma.

Received 11/12/2019

Review began 11/15/2019 Review ended 11/15/2019 Published 11/18/2019

\section{() Copyright 2019}

Robinette et al. This is an open access article distributed under the terms of the Creative Commons Attribution License CC-BY 3.0., which permits unrestricted use, distribution, and reproduction in any medium, provided the original author and source are credited.

\section{Case Presentation}

A 67-year-old female presented with a raised and pruritic ovoid swelling located left of the medial canthus and noted excessive tearing from her left tear duct. She was seen by her ophthalmologist who probed and irrigated her canaliculi with a steroid and antibiotic in late November 2018. Her epiphora improved, however, she noted a pea-size mass and thickening which remained. Non-contrast computed tomography (CT) of the paranasal sinuses on December 19, 2018, showed an 8x10x14 mm ovoid, well-circumscribed collection of soft tissue in the left medial canthus involving the lacrimal drainage apparatus as seen in Figure 1 [7]. She reported intermittent pressure in the left eye on December 27, 2018. 


\section{Cureus}

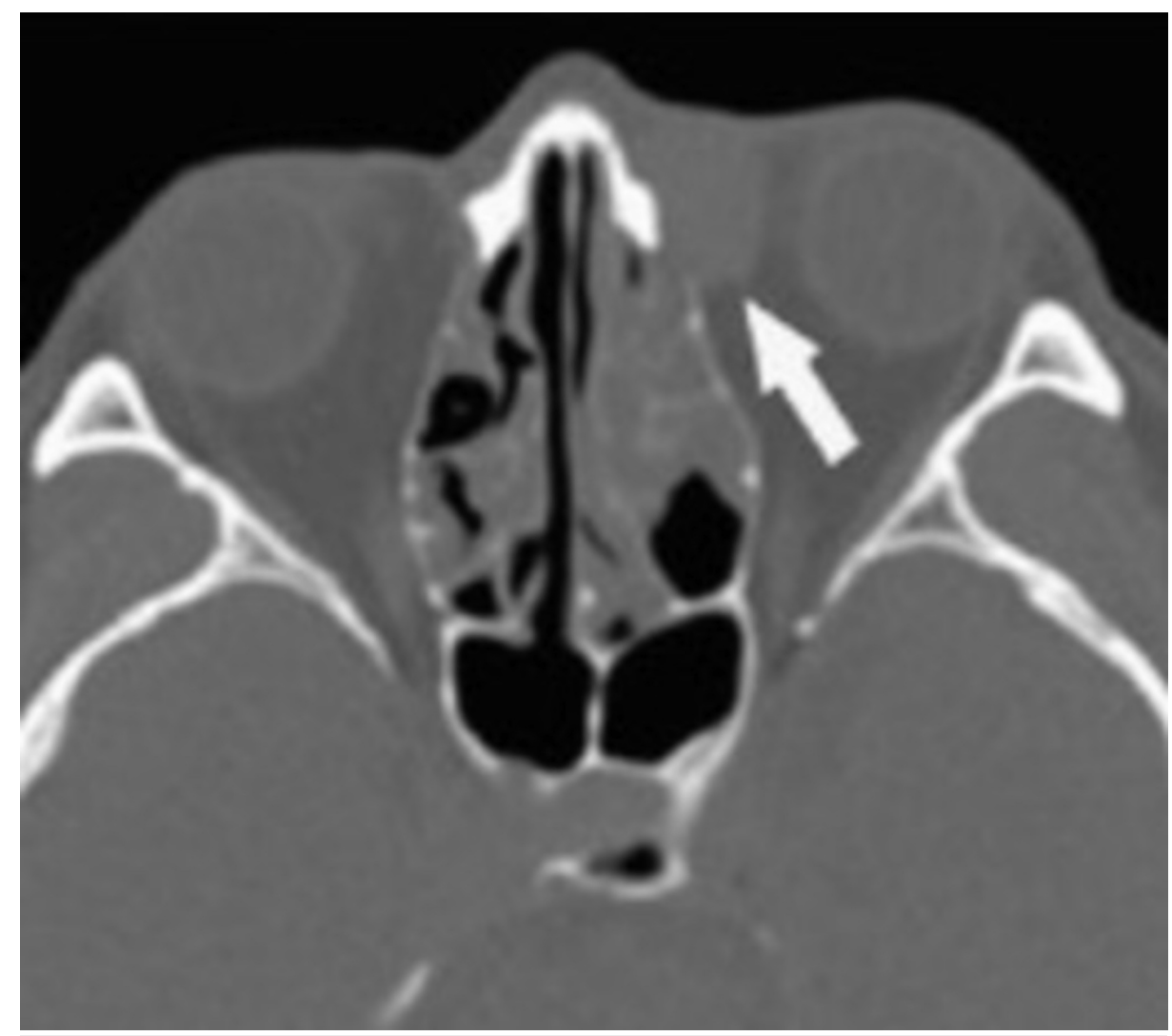

FIGURE 1: Computed tomography demonstrating homogeneous soft tissue density in the medial surface of the globe indicated by the tip of the arrow.

She then underwent endoscopic dacryocystorhinostomy on January 14, 2019, and was found to have what was thought to be a dacryocystocele, which was subsequently biopsied. Pathology of the dacryocyst was concerning for large B-cell malignant lymphoma as seen in Figure 2 [7]. The specimen was cluster of differentiation 45 (CD45) positive, S100 negative, A/E 1/3 essentially negative, B-cell leukemia/lymphoma 1 (BCL1) negative, BCL2 scattered nondescript positivity, BCL6 scattered positivity, CD3 scattered positivity in T cells, CD5 positive in T cells, CD20 positive, CD23 essentially negative, CD43 positive in T cells, and CD79a positive in large atypical cellular infiltrate. nodular lymphocyte-predominant Hodgkin lymphoma (MUM1) was negative, and Ki67 was $\sim 80 \%$. The slides were then reviewed at the University of Virginia Health System University Hospitals labs, which again read as markedly atypical large cell infiltrate favor large cell malignant lymphoma. 


\section{Cureus}

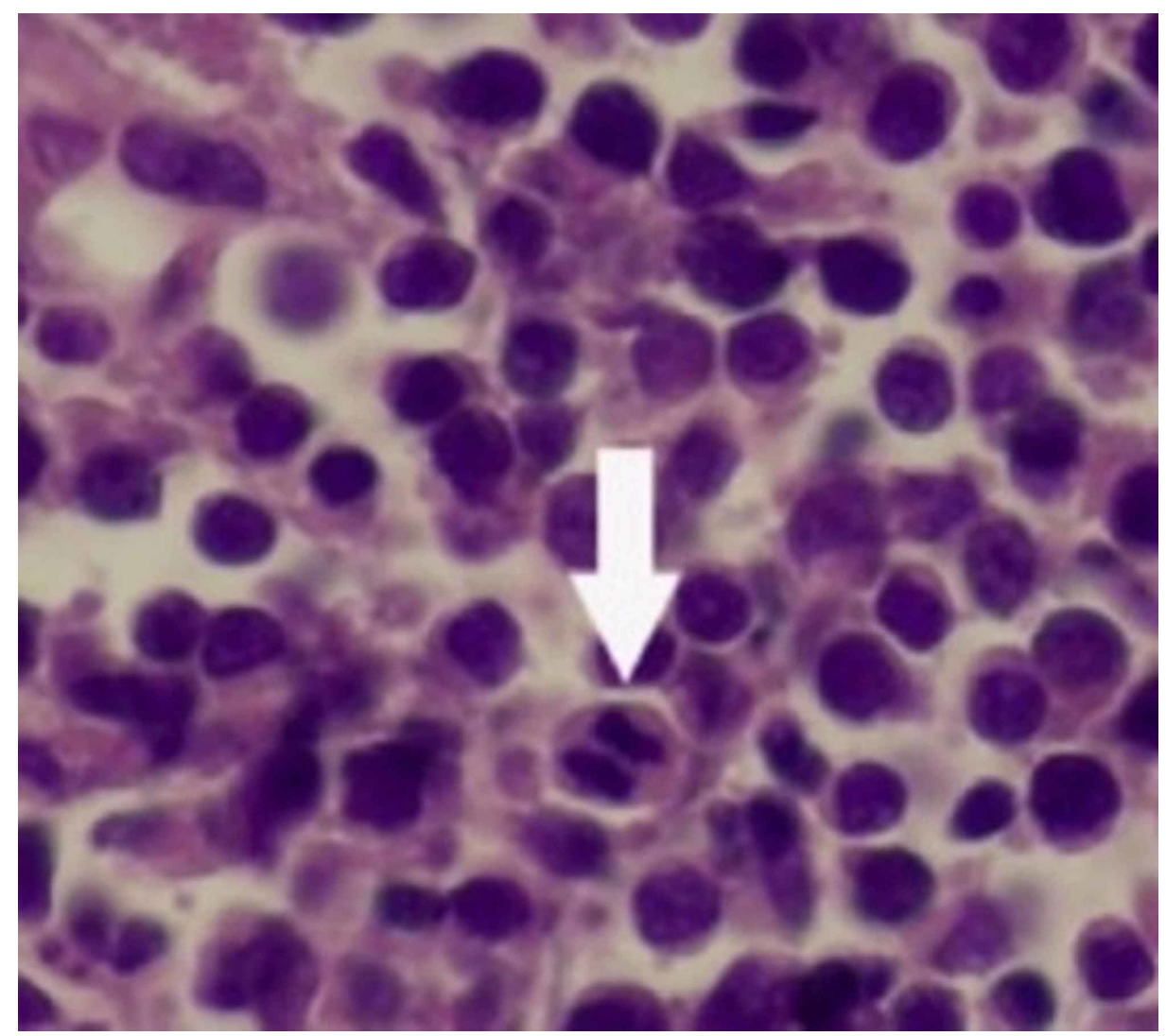

FIGURE 2: Histopathological studies with hematoxylin and eosin stain demonstrate neoplastic cells with high mitotic activity and variable size.

The patient completed staging with positron emission tomography-computed tomography (PET/CT), had subsequent bone marrow biopsies with no bone marrow involvement, and labs followed by prognosis. She is currently receiving chemotherapy regimens and has remained stable since her last office visit with her otolaryngologist.

\section{Discussion}

Primary Non-Hodgkin's lymphoma of the lacrimal sac is extremely rare, and patients are often older and female [6]. The symptoms of DLBCL are usually atypical and nonspecific, which often leads to the original misdiagnosis of dacryocystitis [4-5]. The most presenting features are epiphora (96\%), swelling in the lacrimal sac region (75\%), and acute dacryocystitis (31\%) [3]. Our patient presented with features of epiphora, which was improved after steroid and antibiotic treatment by her ophthalmologist. She also presented with swelling and intermittent pressure on the left eye.

In a literature review of 17 case-control studies, a total of 3865 histopathologically examined lacrimal sac wall biopsy specimens from 3662 patients taken during dacryocystorhinostomy were analyzed, and it was found that $45 \%$ of primary lacrimal sac malignant neoplasms were not suspected [8]. This evidence highlights the importance of early diagnosis and the significance of routine biopsy during dacryocystorhinostomy for suspected dacryocystitis. Our patient was originally diagnosed with dacryocystitis and received prompt dacryocystorhinostomy, which was subsequently biopsied without any particular concern for malignancy. Prompt and precise diagnosis occurred in $<15 \%$ in some cases while others were unintentionally diagnosed during other procedures [9-10]. Our patient was originally suspected to have dacryocystitis and was diagnosed with large B-cell lymphoma two months later. This demonstrated the potential urgency for early diagnosis and treatment for possible malignancy of the lacrimal gland.

Most cases involve possible surgical resection, chemotherapy, and/or radiation. This management involved a high success rate with local disease control; however, with systemic disease involvement, $15 \%$ died after 18 months [3]. After surgical resection, our patient began receiving chemotherapy treatment and has been stable as of her last office visit.

\section{Conclusions}

Malignant lymphoma of the lacrimal gland are rare and can easily imitate dacryocystitis. We present a case 
of a 67-year-old woman with primary diffuse large B-cell lymphoma (DLBCL) of the lacrimal sac who was originally diagnosed with dacryocystitis. She presented with features of epiphora, swelling, and intermittent pressure on the left eye. Due to the infiltrating nature of these tumors and differential variants, early diagnosis and treatment is essential to optimize outcomes. This case report adds to the urgency that prompt and precise diagnosis and treatment are key.

\section{Additional Information \\ Disclosures}

Human subjects: Consent was obtained by all participants in this study. Conflicts of interest: In compliance with the ICMJE uniform disclosure form, all authors declare the following: Payment/services info: All authors have declared that no financial support was received from any organization for the submitted work. Financial relationships: All authors have declared that they have no financial relationships at present or within the previous three years with any organizations that might have an interest in the submitted work. Other relationships: All authors have declared that there are no other relationships or activities that could appear to have influenced the submitted work.

\section{References}

1. Stefanyszyn MA, Hidayat AA, Pe’er JJ, Flanagan JC: Lacrimal sac tumors. Ophthal Plast Reconstr Surg. 1994, 10:169-184. 10.1097/00002341-199409000-00005

2. Levy-Clarke GA, Chan C-C, Nussenblatt RB: Diagnosis and management of primary intraocular lymphoma . Hematol Oncol Clin North Am. 2005, 19:739-749. 10.1016/j.hoc.2005.05.011

3. Singh S, Mohammad JA: Lymphoproliferative tumors involving the lacrimal drainage system: a major review. Orbit. 2019, 10.1080/01676830.2019.1634104

4. de Palma P, Ravalli L, Modestino R, Grisanti F, Casillo F, Marzola A: Primary lacrimal sac B-cell immunoblastic lymphoma simulating an acute dacryocystitis. Orbit. 2003, 22:171-175. 10.1076/orbi.22.3.171.15620

5. Palamar M, Midilli R, Ozsan N, Egrilmez S, Sahin F, Yagci A: Primary diffuse large B-cell lymphoma of the lacrimal sac simulating chronic dacryocystitis. Auris Nasus Larynx. 2011, 38:643-645.

6. Sjo LD, Ralfkiaer E, Juhl BR, et al.: Primary lymphoma of the lacrimal sac: an EORTC ophthalmic oncology task force study. Br J Ophthalmol. 2006, 90:1004-1009. 10.1136/bjo.2006.090589

7. Tsao WS, Huang TL, Hsu YH, Chen N, Tsai RK: Primary diffuse large B cell lymphoma of the lacrimal sac . Taiwan J Ophthalmol. 2016, 6:42-44. 10.1016/j.tjo.2014.11.002

8. Koturović Z, Knežević M, Rašić DM: Clinical significance of routine lacrimal sac biopsy during dacryocystorhinostomy: A comprehensive review of literature. Bosn J Basic Med Sci. 2017, 17:1-8. 10.17305/bjbms.2016.1424

9. Montalban A, Lietin B, Louvrier C, Russiera M, Kemeny JL, Moma T, Gilain L: Malignant lacrimal sac tumors. Eur Ann Otorhinolaryngol Head Neck Dis. 2010, 127:165-172. 10.1016/j.anorl.2010.09.001

10. Tucker N, Chow D, Stockl F, Codere F, Burnier M: Clinically suspected primary acquired nasolacrimal duct obstruction. Clinicopathologic review of 150 patients. Ophthalmology. 1997, 104:1882-1886. 10.1016/s0161-6420(97)30012-8 